\title{
Pengembangan Strategi Penjualan Hasil Pengolahan Kapuk Di Desa Sumurdalam Melalui Pemasaran Online
}

\author{
Moh. Ainol Yaqin ${ }^{1 *}$, Jam'iyyatul Munawwaroh ${ }^{2}$, Diana Khotibi ${ }^{3}$ \\ ${ }^{1,2}$ Program Studi Informatika, Universitas Nurul Jadid Paiton, Indonesia \\ ${ }^{3}$ Program Studi Fakultas Agama Islam, Universitas Nurul Jadid Paiton, Indonesia \\ Email: ${ }^{1}$ ainolyaqin09@gmail.com, ${ }^{2}$ jamiyyatul19@gmail.com, ${ }^{3}$ dianakhotibi32547@gmail.ac.id
}

\section{INFORMASI ARTIKEL}

\section{Data artikel:}

Naskah masuk, 11 Oktober 2019

Direvisi, 29 November 2019

Diterima, 16 Januari 2020

\section{Kata Kunci:}

Kasur

Kapuk

Home industry

Pemasaran

Online

\begin{abstract}
ABSTRAK
Abstract- Sumurdalam Village is a village located in Besuk Subdistrict, Probolinggo Regency. The village of Sumurdalam is well-known as a mattress producing village which is a home industry. Villagers of Sumurdalam market their production of mattresses, pillows and bolsters with three marketing techniques, namely: Supplying manufactured goods to areas that have become their regular customers (for example: maron, drainage, shallow, etc.) markets, peddling around, and receiving orders from customers. Technology is developing rapidly and widely. One proof of the development of technology is the creation of online-based sales applications. Kapok entrepreneurs in the village of Sumurdalam have not applied this sales strategy. So, by utilizing existing technology, we are collaborating with partners in the Sumurdalam Village to introduce sales of cotton based products online. The online store application that we apply, namely Shopee, Bukalapak, and Tokopedia.
\end{abstract}

\begin{abstract}
Abstrak- Desa Sumurdalam merupakan desa yang terletak di Kecamatan Besuk Kabupaten Probolinggo. Desa Sumurdalam terkenal sebagai desa pemproduksi kasur yang bersifat home industry (usaha rumahan). Warga Desa Sumurdalam memasarkan hasil produksi kasur, bantal, dan guling dengan tiga teknik pemasaran, yaitu: Memasok barang hasil produksi ke daerah yang telah menjadi langganan tetap mereka (misal: pasar maron, tiris, wangkal, dan lain sebagainya), menjajahkan keliling, dan menerima pesanan dari pelanggan. Teknologi berkembang secara cepat dan meluas. Salah satu bukti akan adanya perkembangan teknologi ialah terciptanya aplikasi penjualan berbasis online. Para pengusaha kapuk yang ada di desa Sumurdalam belum mengaplikasikan strategi penjualan ini. Jadi, dengan memanfaatkan teknologi yang ada maka kami bekerjasama dengan mitra Desa Sumurdalam untuk memperkenalkan penjulan produk kapuk berbasis online. Adapun aplikasi toko online yang kami terapkan, yaitu Shopee, Bukalapak, dan Tokopedia.
\end{abstract}




\section{Korespondensi:}

Moh. Ainol Yaqin

Program Studi Informatika, Universitas Nurul Jadid Paiton

Jl. PP Nurul Jadid, Dusun Karanganyar Paiton Probolinggo, Indonesia

\section{PENDAHULUAN}

Desa Sumurdalam merupakan desa yang terletak di Kecamatan Besuk Kabupaten Probolinggo. Warga di desa tersebut didominasi oleh rakyat kecil menegah yang sebagian besar warganya menjadikan industri pembuatan kasur berbahan dasar kapuk sebagai alternatif dalam mencukupi kebutuhan finansial, selain bertani dan berternak. Sekitar 70 persen warga Sumurdalam menggeluti industri kasur kapuk. Hal ini telah mereka lakukan turun temurun dari sesepuh mereka bertahun-tahun yang lalu. Namun sayangnya, proses pembuatan kasur kapuk Desa Sumurdalam hanya sebatas home industri (usaha rumahan) dengan alat-alat yang terbilang masih sangat sederhana. Semuanya dikelola sendiri oleh pemilik usaha, sedangkan tenaga kerjanya sebatas dari keluarga dan kerabat dekat. Karakterisik semacam ini menurut Kuncoro termasuk dalam contoh industri kecil (Mulyani, 2011). Industri merupakan suatu bentuk kegiatan perekonomian yang memanfaatkan sumberdaya alam serta mengolah bahan baku sehingga menjadi sesuatu yang lebih bermanfaat dan bernilai ekonomi tinggi (Suparmoko, 2014). Industri sendiri, berperan penting dalam meningkatkan perekonomian Negara serta dalam menyejahterakan rakyat.

Kelangkaaan kapuk saat ini tidak membuat industri Kasur Desa Sumurdalam berhenti dalam memproduksi. Pengusaha meyiasati bahan baku pembuatan kasur kapuk dengan cara memasok dari daerah-daerah sekitar seperti pati, dan lain sebagainya. Selain itu, warga Desa Sumurdalam selain memanfaatkan kapuk sebagai bahan utama dari pembuatan kasur, mereka terkadang menjual sebagian

dari kapuk kepada industri-industri lain yang sama-sama memproduksi kapuk. Dan permasalah lainnya dalam segi pemasaran yang masih menggunakan cara manual yaitu dijajahkan lewat pintu ke pintu hal ini sangat tidak efesien dan efektif, penjualan secara konvensional (Mulyana, 2019), sehingga sampai ke kota sebelah, hal tersebut tentunya membutuhkan biaya, seperti transport dan akomudasi lainnya.

Seiring dengan perkembangan zaman, kasur kapuk di desa tersebut mulai punah keberadaannya. Kemajuan teknologi, adanya berbagai jenis kasur yang beredar di pasaran, kurangnya daya kreasi dalam memasarkan produk serta masih taradisionalnya sistem pemasaran warga Desa Sumurdalam, menyebabkan kasur produksi di desa tersebut belum dikenal luas sehingga berdampak pada ketidak stabilan omset yang dihasilkan.

Menyikapi fenomena tersebut, agar produksi kasur kapuk warga desa Sumur Dalam dapat perkembang, perlu adanya setrategi pemasaran (marketing mix) yang tepat sesuai degan perkembangan zaman. Dalam setrategi pemasaran kasur kapuk warga desa Sumurdalam, terdapat beberapa hal yang perlu dilaksanakan seperti strategi produk (logo, merk, kemasan dan label) (Susetyarsi, 2012), strategi harga, dan strategi distribusi (baik online/offline). Keempat, strategi promosi. Strategi pemasaran yang tepat sangat berpengaruh dalam keberhasilan suatu usaha, sehingga produk yang dihasilkan tetap eksis di pasaran. Pentingnya setrategi pemasaran diungkapkan oleh Kasmir dalam bukunya "Kewirausahaan". Ia mengatakan bahwa "Sebaik apapun segmentasi pasar, sasaran, serta posisi pasar tidak akan berjalan tanpa setrategi yang tepat" (Kamil, 2015)

Selain setrategi pemasaran yang tepat, dalam meningkatkan omset penjualan, perlu adanya adanya produk-produk baru berbahan dasar kapuk seperti, kasur lantai, boneka, dan produk-produk lainnya. Sehingga produk industri kapuk Desa Sumurdalam tiak hanya dikenal dengan produk kasur kapuknya akan tetapi kerajinan berbahan dasar kapuk. 


\section{METODE PELAKSANAAN}

Pelaksanaan dari kegiatan Kuliah Kerja Nyata dan Pengabdian kepada Masyarakat (KKN-PkM) Universitas Nurul Jadid dilaksanakan pada bulan Agustus - November dan bekerjasama dengan beberapa mitra, salah satunya adalah desa Sumurdalam. Peserta KKN-PkM di desa Sumurdalam terdiri dari 12 peserta (1 Dosen Pembimbing Lapangan dan 11 orang anggota) yang terdiri dari 3 peserta dari fakultas teknik dan 8 peserta dari fakultas agama islam. Adapun bagan metode kegiatan seperti Gambar 1.

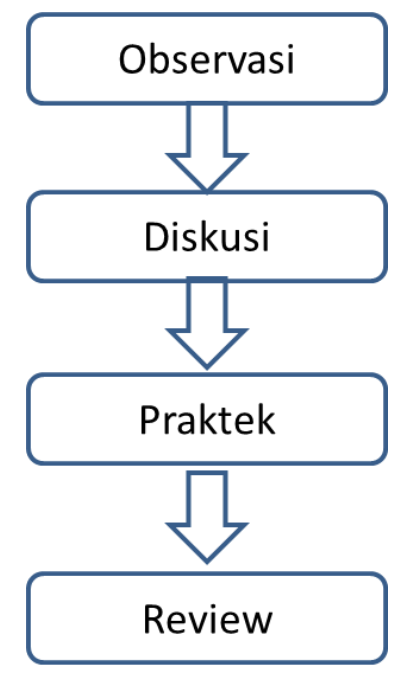

Gambar 1. Metode Kegiatan

Metode kegiatan yang kami lakukan untuk menjalankan program unggulan kami ialah, (1) Observation (observasi); Pencarian beberapa informasi pendukung (Maria \& Aprianti, 2009) terkait pengusaha kapuk dan desa Sumurdalam yang ada di desa Sumurdalam dengan bertanya kepada kepala desa Sumurdalam, dan langsung kepada beberapa pengusaha kapuk desa Sumurdalam; (2) Discussion (diskusi). Setelah mendapatkan beberapa informasi dari observasi, maka kami diskusikan bersama DPL dan tim untuk membentuk susunan kegiatan yang akan dilakukan di desa Sumurdalam untuk mensuskseskan program dari kelompok kami.; (3) Practice (praktek). Melakukan kegiatan apa saja yang telah terbentuk sebelumnya terutama pelatihan penjualan produk (Susanto, Azis, \& Irjayanti, 2016) berbasis online kepada beberapa pengusaha kapuk desa Sumurdalam; (4) Review (melihat ulang).
Memantau hasil program pelatihan yang telah dilakukan untuk melihat apa saja masalah (Susanto et al., 2016) (Arum \& Haryanti, n.d.) yang dihadapi para pengusaha kapuk dalam mengaplikasikan strategi penjualan yang baru.

Pelatihan yang dilakukan dimulai dari 26 September 2019 sampai dengan 27 September 2019. Pelatihan yang diberikan, memanfaatkan toko online yang telah ada saat ini yaitu Shopee, Bukalapak, dan Tokopedia. Dari 6 pengusaha yang mengikuti pelatihan, 2 pengusaha kapuk mengaplikasikan Shopee, 2 pengusaha kapuk mengaplikasikan Tokopedia, dan 2 pengusaha mengaplikasikan Bukalapak.

Tabel 1. Data Peserta Pelatihan Penjualan produk berbasis online

\begin{tabular}{|c|c|c|}
\hline No & Peserta Pelatihan & Tanggal \\
\hline 1 & H. Ali Ridho & 26 September 2019 \\
\hline 2 & Luluk & 26 September 2019 \\
\hline 3 & Muhammad & 26 September 2019 \\
\hline 4 & Ami & 27 September 2019 \\
\hline 5 & Ahyati & 27 September 2019 \\
\hline 6 & Wasiah & 27 September 2019 \\
\hline
\end{tabular}

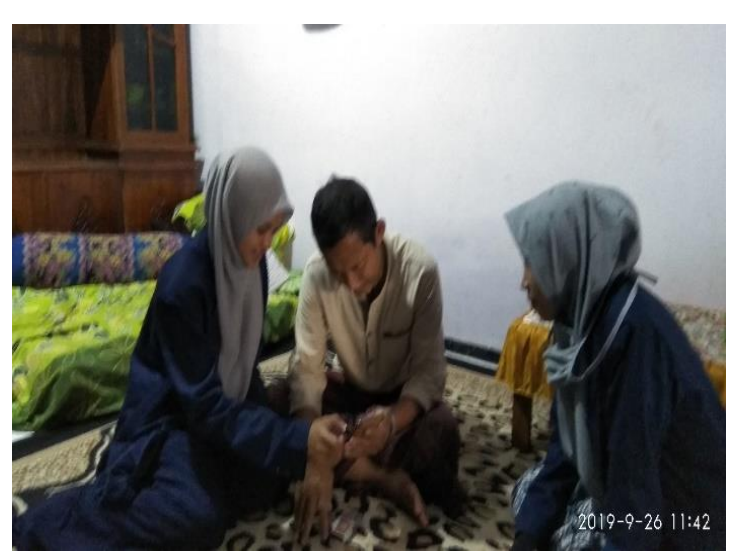

Gambar 2. Proses pemberian materi e-learning kepada salah satu pengusaha kapuk desa sumurdalam

\section{HASIL DAN PEMBAHASAN}

Teknologi berkembang secara cepat dan meluas (Yuniarti, 2009). Salah satu bukti akan adanya perkembangan teknologi ialah terciptanya aplikasi penjualan berbasis online. Para pengusaha kapuk yang ada di desa Sumurdalam belum mengaplikasikan strategi penjualan ini. Jadi, dengan memanfaatkan teknologi yang ada maka kami bekerjasama 
dengan mitra Desa Sumurdalam untuk memperkenalkan penjulan produk kapuk berbasis online. Adapun aplikasi toko online yang kami terapkan, yaitu Shopee, Bukalapak (Sari, 2018), dan Tokopedia. Ada beberapa kendala atau masalah yang kami hadapi, diantaranya 1) ongkos kirim, 2) Rekening tabungan, 3) Pemasaran, 4) Jaringan internet, 5) Gagap Teknologi.

Pelatihan yang kami lakukan telah membuat dari ke-6 pengusaha kapuk yang ada di desa Sumurdalam memiliki sedikitnya satu toko online untuk memasarkan produk kapuk mereka dan mereka telah memasarkan sedikitnya 1 produk kapuk (kasur, bantal, dan guling) di masing - masing toko online yang mereka miliki.

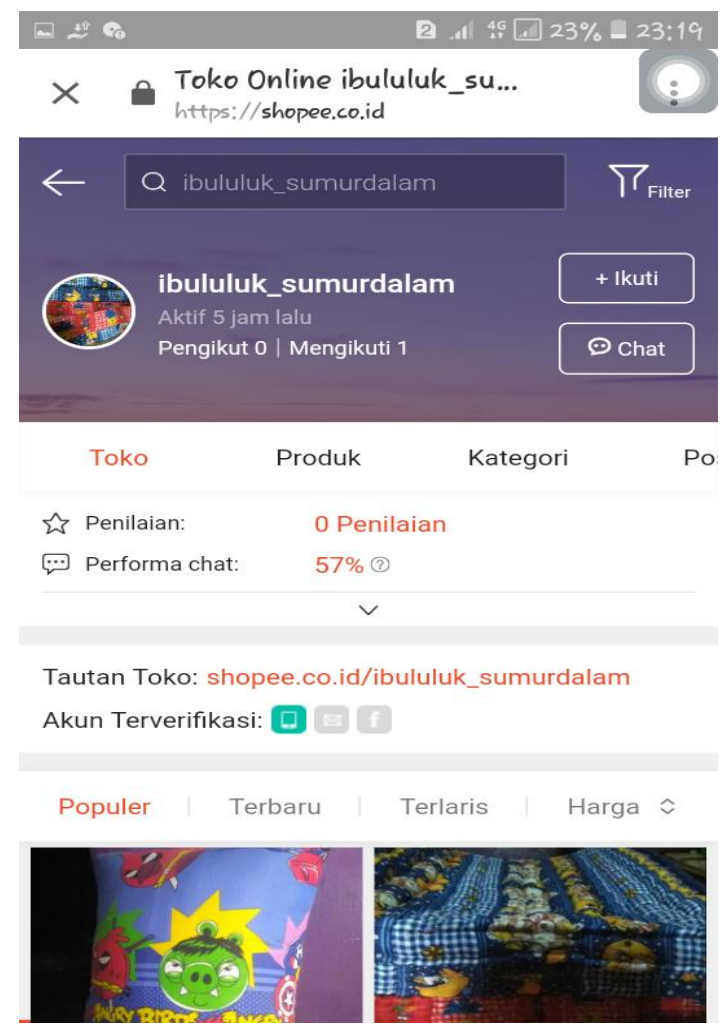

Gambar 3. Toko online salah satu pengusaha kapuk desa Sumurdalam

\section{KESIMPULAN}

Desa Sumurdalam merupakan salah satu desa pengahasil produk berbahan dasar kapuk terbesar di Kabupaten Pobolinggo. Produknya meliputi kasur, guling dan bantal. Industri kapuk di desa tersebut hanya sebatas home industri yang seluruh pengerjaannya dilakukan oleh pemilik usaha beserta kerabat dekatnya.
Proses pembuatannya dilakukan secara manual dengan alat-alat yang sederhana. Gagap teknologi, dan sistem pemasaran yang masih sangat tradisional, membuat kasur kapuk Desa Sumurdalam kurang dikenal oleh masyarakat yang berada diluar Kabupaten Probolinggo.

Solusi yang ditawarkan dalam menyelesaikan masalah diatas adalah dengan membuatkan toko secara online dengan memafaatkan tiga Unicorn (Hutami, 2019) yang telah ada, diantaranya: Shopee, Tokopedia dan Bukalapak. Metode yang digunakan dalam mensukseskan program tersebut (1) Observasi (2) Diskusi (3) Praktek dan (4) Review/melihat ulang.

\section{UCAPAN TERIMA KASIH}

Terimakasih kepada para pengusaha kapuk desa Sumurdalam atas bantuan informasi yang mereka berikan selama KKNPkM berlangsung. KKN-PkM dilakukan selama 4 bulan (Agustus - November).

\section{DAFTAR PUSTAKA}

Arum, T. S., \& Haryanti, R. H. (n.d.). Program pemberdayaan tunagrahita melalui kerajinan keset di desa karangpatihan kecamatan balong kabupaten ponorogo. Jurnal Wacana Publik, 1(3), 16-23.

Hutami, L. T. H. (2019). Intensi penggunaan electronic wallet generasi millenial pada tiga startup "unicorn" indonesia berdasarkan modifikasi tam. Jurnal Manajemen, 8(2), 136-145.

Kamil, A. (2015). Industri kreatif indonesia: pendekatan analisis kinerja industri. Jurnal Media Trend, 10(2), 165-182.

Maria, A., \& Aprianti, I. (2009). Aplikasi sistem informasi pendukung bisnis penjualan pada $\mathrm{pd}$. susan palembang.

Mulyana, M. (2019). Strategi distribusi.

Mulyani, E. (2011). Model pendidikan kewirausahaan di pendidikan dasar dan menengah. jurnal ekonomi dan pendidikan, $8(1)$.

Sari, A. Y. (2018). Analisis terhadap penerapan pajak atas transaksi $e$ commerce.

Suparmoko, M. (2014). Ekonomi sumber daya alam dan lingkungan.

Susanto, R. J., Azis, A. M., \& Irjayanti, M. 
(2016). Pelatihan penggunaan komputer dan penggunaan media sosial berbasis internet.

Susetyarsi, T. (2012). Kemasan produk ditinjau dari bahan kemasan, bentuk kemasan dan pelabelan pada kemasan pengaruhnya terhadap keputusan pembelian pada produk minuman mizone di kota semarang. Jurnal STIE Semarang, 4(3), $1-28$.

Yuniarti, R. (2009). Optimalisasi peralihan penggunaan teknologi wifi ke wimax. Tugas Akhir. Tehnik Informatika Fakultas Ilmu Komputer Universitas Sriwijaya. 